\title{
Museology and Research - THE PRESENT SitUATION in a Norwegian Perspective
}

\author{
John Aage Gjestrum
}

In 1993 the Norwegian Museums Association celebrated its 75th anniversary with a conference attended by numerous museum professionals from all parts of Norway. The role of museology was one of the issues covered by the conference. As an introduction I want to quote two statements given by speakers at this conference:

"If the proposal to introduce a Norwegian museum training programme should continue to require time and resources - seminars, reports, projects etc. - it certainly represents a deadlock and it leads us astray. The personnel with responsible scientific positions in Norwegian museums have an adequate training both when it comes to disciplinary diversity and depth.» (Niemi 1994:27)

"I want to state, here and now, that museology offers training for a practical job. It is a misunderstanding to believe that it should be possible to be a 'museologist', one who studies museums in the abstract without having a basis and anchorage in the real disciplines which are the genuine roots of the museums, the reason for their existence. It is unrealistic, thoughtless and naive.» (Hohler 1994:42)

Those statements by Einar Niemi, Professor of History, and Erla B. Hohler, Professor of Art History, have great significance. They clearly express positions strongly favoured by museum professionals and clarify the harsh climate facing attempts to introduce the concept of museology.

A key question is: in what way do the disciplines dealing with museum objects relate to the museum as an institution? Does Professor Hohler correctly describe the relationship when she states that these 'real disciplines' are the 'genuine roots' of the museums, and - in her words - 'the reason for their existence'? It is important to get an answer to those questions. If Professor Hohler is right, supposably the 
6 basis for museology as a field of scholarship disappears. I will return to this question towards the end of my paper.

The viewpoint advocated by Professor Niemi that there is no need for any specific museological training beyond the disciplines required for museum curators today, seems to be based on the same assumption - that is: curatorial work within the museum institution is exactly the same as scholarship in the corresponding disciplines at the universities. To what extent is this assumption correct? Or, on the contrary, is it true that the university disciplines have gained a position of power in the museums which they must now defend, while the same time precluding a proper understanding of the museum institution itself?

Among many museum professionals the museum institution and museum tasks are seen as 'given' once and for all, a priori, and do not need to be questioned.

One of the first scholars to advocate museology as a discipline in its own right was the Czech Jiri Neustupny in his doctoral thesis from 1950. Thirty years later he writes:

It is the common experience of those connected with the organization of museum work that museum personnel deny in practice the usefulness of museology. Personal experience, sometimes supplemented by the experience of one's predecessors is elevated to the role of a theoretical model (Neustupny 1980:28).

The scope and possibilities of museological research go far beyond what my paper can possibly cover. I will, however, try to raise some important aspects by referring to some actual examples and topics.

\section{MUSEOLOGY - A LONG SAD STORY ABOUT THE DIFFICULT BIRTH OF A NEW DISCIPLINE}

We do not find a lot written about the birth and early history of museums and in the same way the history of museology as a discipline is rarely dealt with and is rather obscure. Questions raised relating to a scientific theory of museums and museum work can however be traced back to the 18 th century.

The term museography was first used in 1727 by Caspar Friedrich Neckelius in Vienna. Museology itself was first used in 1869 by Philipp Leopold Martin in his 'Praxis der Naturgeschichte', a handbook on taxidermy. At that time both terms were applied to practical aspects of the collection-oriented disciplines. The first periodical in museology was published in Dresden, Germany: 'Zeitschrift für Museologie und Antiquitätenkunde' (18781885). From then on handbooks, training courses, journals and other activities have contributed to the establishment of a widespread basic paradigm for the understanding of museums and their field of action (Mensch 1992, Waidacher 1993).

In a wider context the International Office of Museums was founded in 1926, as an organisation within the League of Nations. After the Second World War its successor The International Council of Museums, ICOM, was founded in 1946.

At the 7th General Conference of ICOM in New York (1965) the main theme was the training of museum personnel. The Conference resolved that university courses in theoretical museology should be developed. The International Committee for the Training of Personnel, ICTOP, with- 
in ICOM, was founded in 1968. The International Committee for Museology, ICOFOM, started its work in 1977.

The international significance of museology was thus officially recognized and, together with the emphasis put on training, in some countries produced certain results, because leading professionals had participated in ICOM activities. Initiatives were taken in Norway in 1964 with a view to introducing museum training courses and in 1972 a proposal was made to establish museology at the University of Bergen. A committee chaired by Professor Robert Kloster stated concerning the curatorial staff that:

...it is an obvious insufficiency that their professional training does not include museological elements. As a matter of fact it might explain the stagnation in our museums. (Kloster 1972:18-19)

According to the committee some museological as well as museographic qualifications must be required of applicants for curatorial positions in museums. The committee reported that none of the Nordic countries offered museological training. The Kloster committee presented the museum studies programme available at Leicester University since 1966 as a model.

The introduction of museology as a discipline for everybody who aims at a curatorial career must be seen as a necessary contribution to the strengthening of museum work as an attractive profession. It will add an element of theoretical reflection on the idea of the museum which has so far been missing and thereby stimulate recruitment to the profession. (Kloster 1972)
With reference to this argument the Kloster committee advised the University of Bergen to examine the possibilities of establishing museology as a discipline at the university, then to discuss the question with the other Norwegian universities. However this proposal led nowhere.

During the 1980s ICOFOM played an important role in bringing museology onto the agenda. MUWOP 1 ('Museological Working Papers') was presented in 1980 as its first publication. In 1983 Vinos Sofka became the president of ICOFOM and he managed to publish the ICOFOM Study Series (ISS) in an impressive 16 volumes (1983-89). A large number of ICOM members from all parts of the world served on the committee, which became the second largest international committee of ICOM. The manner in which the publishing of the Study Series was organized, enabled a large number of members to participate in the debate on museological issues, although only a few could actually be present at the committee meetings.

*In the 1950 s and 60 s the prevalent definition of museology was "the study of the purpose and organisation of museums" (Unesco, Rio de Janeiro 1958). In the international debate of the last twenty years a broader definition of the purpose and content of museology has emerged. According to this the concept of museology must include a description and analysis of how various cultures relate to the material remains from their past which is necessary in order to understand how the cultural heritage is constructed by different collective and individual initiatives and how institutions and structures have been developed for the purpose of safe- 
JOHN AAgE GJESTRUM

guarding and communicating the heritage (Ågren 1993:61).

As a consequence the role in public culture of the historical content in the physical environment must also be included in museological study. The following is a general definition of museology as it has recently been proposed by Friedrich Waidacher:

The substance of museology deals with a specific human mode of understanding and evaluating the material world. This relation between man and the world should be called 'Musealität'. This concept means that selected objects are considered as symbols (signs, icons) for meanings and ideas of such value that they must be saved and communicated to the members of the society for an unlimited future. (Waidacher 1993:34)

Through musealisation museum objects, musealia, are given a secure place in the material cultural heritage - or, as we could also put it - the environmental heritage. The process accordingly includes the natural heritage, as it is culturally selected. Museological objects therefore include single artefacts, buildings as well as sites and areas of historical significance. Together they constitute the material heritage as a social phenomenon (Ågren 1993:62).

\section{FROM UNCRITICAL TRUTHS TO FALSE MYTHS}

In 1983 J. Lynne Teather published her doctoral thesis Museology and its traditions, with a special focus on England 1845-1945. In her thesis she underlined how inaccuracies concerning museums and museum work grow into myths and how myths become dogmas. Thus references are con- stantly made to a myth of cabinets of curiosities as being dusty accumulations of unrelated objects amassed according to a prevalent fashion by ignorant aristocrats. Another myth actively sustained, is the notion of museums in the past being isolated from the broader social reality of their days. The development of museology must counteract such simplifications in order to make a more truthful evaluation of the museum tradition in today's debate. As in the contemporary situation the past of the museum is much more complex than popular myths want to make us believe (Teather 1983:3).

For almost forty years the Canadian Duncan F. Cameron has been a critical voice in the museum world. He has promoted the view that museums must engage in the social, political, environmental and philosophical issues of the contemporary world. His well-known paper The Museum, a Temple or the Forum, presented to the ICOM General Conference of 1971 has echoed through the museum debate of the ensuing decades. In 1992 he wrote:

Too often we believe we know the origins of our institutions when what we have come to know are the myths and legends of convenience that masquerade as hallowed traditions (Cameron 1992: 379380).

As the standard museum history has been constructed on contemporary myths and legends, research into the early history of our museums is urgently needed. Teather as well as Cameron offers a challenge to museology to take on this task. If their opinion that current museum history is based on myths - the myths must be unmasked! Evidently the statement by 
Professor Hohler that the collection-linked university disciplines form the genuine roots of museums might belong to the category of produced myths.

My task, however, is not to pursue such an investigation, but to present some actual research tasks in museology. Let me, despite this, quote what Hans Aall, the founder of Norsk Folkemuseum (The Norwegian Folk Museum) has himself testified concerning his motives:

...the man (i.e. Aall himself!) lived mostly on romantic ideas and worked on instinct. Sober theory he knew little of... (Aall 1920:2)

\section{MUSEUM LITERATURE}

An especially important question for the definition of museological concepts and the development of a scholarly discourse is the corpus of theoretical literature. Again we shall turn to Neustypni:

[---] it is interesting to observe that many authors of museological publications have little or no knowledge of museological literature. It seems that they are so deeply immersed in their own reflections that they are not interested in ideas and suggestions of others. Articles and books on museology are often confined to their authors' own ideas and other publications are not taken into account, despite the fact that they may correct, or improve upon, the author's conclusions. Although many books and articles on museology have already been written, they are rarely referred to.

[---] This situation does a great damage to museology and many museological publications lose much of their value and usefulness and with them loses also museology as a discipline (Neustupny 1968: 14-15).
It is a common view that literature on museum issues is scarce or totally absent. The real situation is quite the opposite. Most papers exist as articles in journals, but in recent years many books have appeared. Likewise bibliographies are available that facilitate study and research (Woodhead and Stansfield 1989, Shapiro 1990, Documentation Centre of ICOM, Paris). As early as 1971 it is estimated that 115 periodicals existed which dealt with various aspects of museum work, 34 of them were published in English. But only a few offered really new ideas or innovative debate.

The four best-known museum periodicals are Museums Journal (1901-) in England, Museum News (1924-) in the United States, Curator (1956-) published by The American Museum of Natural History and Unesco's Museum (1948-).

Teather has scrutinized these journals and concludes that the material offered is to a great extent anecdotal, summary, dispersed and repetitive. The articles are often general and superficial. Available printed sources are therefore imprecise and research based on them seems hazardous. Qualified bibliographical support is needed to differentiate among the texts. As an aid Woodhead/Stansfield have offered their Keyguide to information sources (1989).

The situation is serious, as becomes evident when you look at doctoral theses in the field. In the period between 1861 and 1981 about 80 theses were published in the United States, half of them dealing with museum education, the others with various aspects of museum work. In England ten theses were presented, eight of them on museum education. But only a 
10 few offer references to previous works in the field. Tutors and examiners alike seem to be insufficiently oriented in relevant literature. Teather thus makes the same observation as Neustupny did 15 years before: nothing seems to prevent the repetitive re-invention of the wheel.

In spite of those deficiencies a body of museum studies does exist, covering a long period of time and many countries and appearing within many different disciplines and accordingly unknown to most people practically or theoretically engaged in museum work.

In addition, in the last ten years the number of museum-related publications has grown rapidly, not least through the work carried out at the Department of Museum Studies at Leicester University. If we look closely it is obvious that most publications today originate from university courses and research. Thus it ought to be meaningful to consider whether we should not carry out the proposal put forward by Professor Kloster in 1972 to be able to set up an establishment with time and economic resources available to pick up, communicate and integrate new museological findings in the international museology field for the benefit of the Norwegian museums.

\section{IDEOLOGIES OF PRESERVATION}

Who said: This must not be lost! What were the criteria and how were they determined? The questions will be considered in the project I am at present working on - Museum, cultural heritage and the community. A study of motives, ideologies and practice. Roros 1891-1991.

The study is far from completed but I am well on the way. Starting with a description and analysis of how the ideas of museum and cultural heritage were introduced and developed in the municipality of Røros through 100 years I will discover the role of the two concepts in the local community and the ideologies which have influenced the process at different stages. What types of museum model have been tried? Are there differences between the attitudes in different agents - those who belong to the local community as subjects and those who come from without and see Røros as an object?

My starting point is the year 1891 when the Association for the Preservation of Historical Monuments ('Fortidsminneforeningen') makes a note that there is one building, Aspasgairden, which should be documented before it disappears. It is delineated and it disappears - to an open air museum, Trøndelag Folkemuseum - in spite of the protests of the local population in Røros. At this stage they want to establish a museum of their own, but they are ignored. The artist Harald Sohlberg gives Røros a place in Norwegian art history when, at the turn of the century, he executes some of his paintings in Røros. When in the 1920's the Custodian of National Monuments, in accordance with the new legislation for the preservation of historic monuments, puts some buildings in Røros on the list of classified buildings, Sohlberg's paintings are an important incentive. Now the idea of a local museum is also put forward resulting in an open air museum outside the town proper. Later that museum is closed and the museum moves into the centre where the old smelting-house is being reconstructed. On the whole a lot of things happen in Røros and 


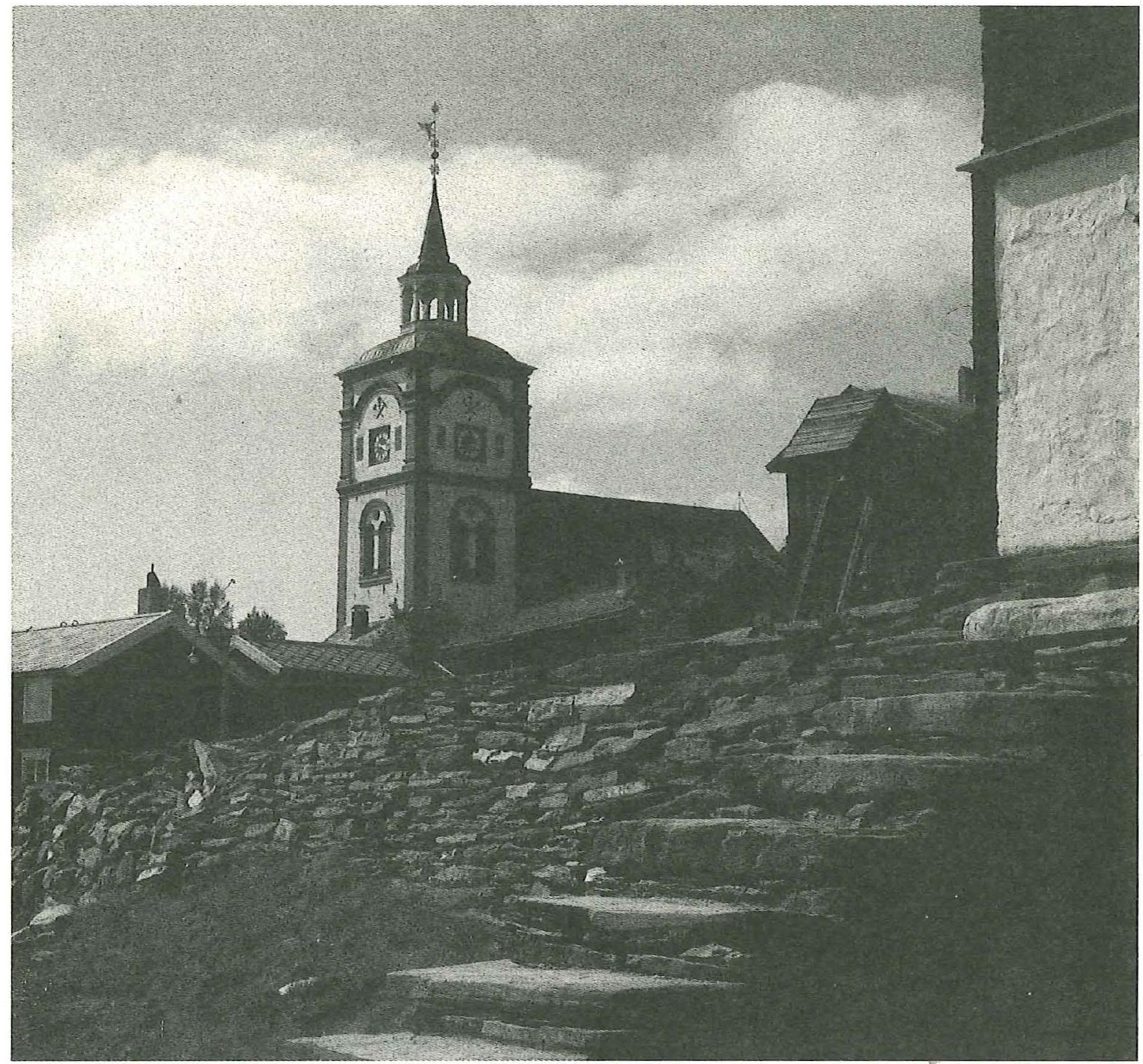

A classic motiv from the wooden mining town of Roros, founded in the mountain interior of Norway in 1644, now a World Heritage Monument. Photo: John Aage Gjestrum 1994.

it is an exciting task to identify the different agents and their actions. Not until 1980 does the Røros museum employ a professional curator. For that reason it is obvious that the museum activity for a long period has been based on other motives than scientific.

The theme of my project also touches upon the Norsk Folkemuseum: in 1925 the Per Amundsa building, which was protected by law, was taken down to make way for a filling station. Modernisation demanded its tribute, although only a couple of years had elapsed after the protection had been confirmed. The Folk Museum 'saved' the building and moved it to Oslo. But with a number of other buildings which had been brought to the open air museum of Bygdøy, the timber was stored awaiting reassembly. In 1967 the filling station was closed. The Association for the Preservation of $\mathrm{Na}$ - 
John Aage Gjestrum

12
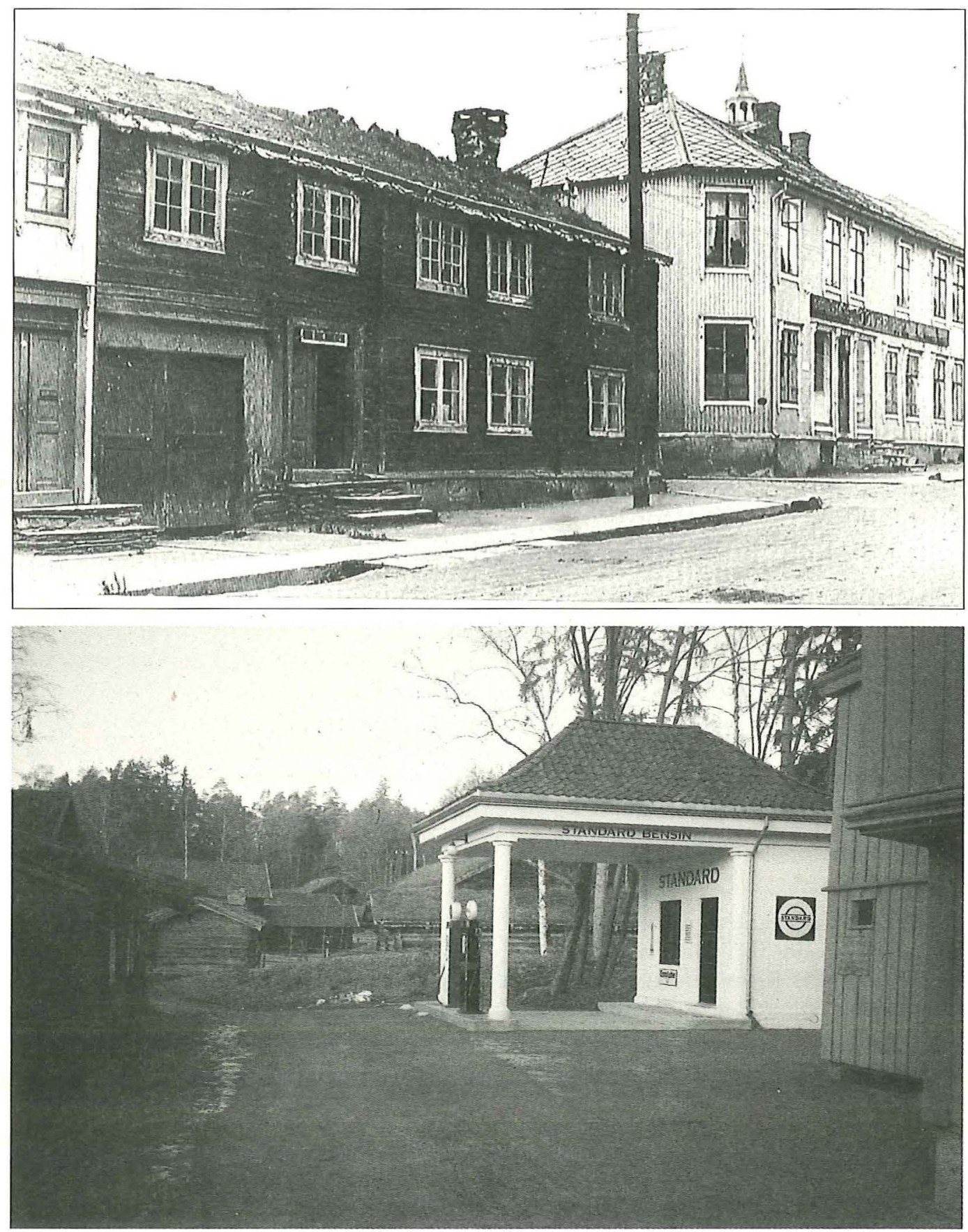
tional Monuments took over the timber from the museum, brought it back and reerected the building on its former site. The project and the remarkable mining town in Røros were afforded a special symbolic meaning in 1975, the Year for the Protection of Architectural Monuments. In 1981 the Custodian of National Monuments had Røros together with three other Norwegian sites listed on Unesco's World Heritage List.

And what did the Norwegian Folk Museum do? They moved an Esso filling station from 1928 to Bygdøy. The station is built of concrete according to American model drawings. The money for the transfer came from the Esso centenary in Norway last year. The museum has thus acquired, according to Director Erik Rudeng in the book published for the centennial, a starting point for a description of Norwegian and international everyday culture, its dependence on American influence and of filling stations as part of the urban and rural environment (Rudeng 1994:54). In its centre the museum in this way is establishing its own antithesis. Moving away from from the creation and cultivation of objects contri-

The Per-Amundsa-building (photo from 1925) in Roros was already a classified monument when it in 1925 had to make way for a filling station. The whole building was moved to Oslo to be included in the collection of Norsk Folkemuseum, the national museum of folk culture. However, the museum never re-erected the building. Instead the Per-Amundsa-building after almost 50 years was again placed on its original site, the filling station was not any longer there.

Today the public at Norsk Folkemuseum can instead study the 20. century filling station, - the income from the Norwegian oil resources has in the last decades changed the concept of Norwegian identity and heritage. Photo: John Aage Gjestrum buting to a national myth we can at last find the museum as an active agent in a late modern - or as others will put it postmodern age.

\section{THE STUDY OF MUSEUM COLLECTIONS}

Gifts and deposits are generally accepted even though we might think that they do not fit into our collections. Otherwise people may say that it is of no use to offer something to a museum that does not care about what is offered. (Aall 1925:14)

Research in museum collections is based on the paradigms of object-oriented disciplines; it is the cognitive contents of objects and object-groups that are studied and systematized.

The often rather random composition of the collection is a considerable problem for the researchers, a situation which many curators have contributed to (cf. the Aall quotation above). For that reason many curators will maintain that the ideal classification of our material reality is achieved by contemporary collecting, where it is possible to collect human life while it still exists - or as in the case of the ready-made house in the Heibergske Samlinger it is put immediately into the museum context instead of first serving in real everyday life. The question is whether the historical museum in this way has taken over what has hitherto been the paradigm of the art museum, where cultural objects achieve their real function only when they enter a museum?

Susan Pearce (1992) made an important observation when she stated that museum collections are not systematically conceived with the selection and acquisition of 
14 one object after another. Large portions of museum collections are acquired as readymade collections, existing before they enter the museum. They are often composed according to a different logic from that normally applied in museums where the taxonomic rules of object oriented disciplines are honoured. A study of collections from such an insight could tell us important things about museum-making processes and the objects as carriers of meaning, about 'Musealität'.

Let me give an example. The wellknown Norwegian poet Olav Aukrust made a private collection in NordGudbrandsdal. In 1926 his collection formed the basis of the newly established Lom Bygdamuseum, and Aukrust made a catalogue of the collection, 355 objects in all. In the handwritten catalogue, page after page, we can read about the objects to which he and his contemporaries attached the symbolic meanings and values which justified their place in the local heritage.

Nr 1-15 cushion-covers, four of them from Lom; 16-20 wedding-sleighs, one made by Skjåk-Ola 'with a sculpted head';

22-37 boxes used when travelling;

38-68 mangling tools, nine of them from Lom;

69-99 porridge-containers;

100-161 objects belonging to the harness;

165-185 tankards.

The list includes purses and locks for purses (15), buckles for belts and shoes (50), cupboards, chairs and spinningwheels. In total only 16 types of objects account for 295 out of 355 objects in the collection, that is $83 \%$.

Why are the details so important? From the facts we can conclude that Aukrust has not intended the collection to represent accurately the living conditions of the time as museum curators prefer to consider their task today. The collection consisted of objects loaded with very specific symbolical and artistic values. The objects have been related to the central core of ideas linked to the most basic events and activities in peasant life, the vital force itself.

- Mangling tools are the gifts of suitors to their girl-friends.

- The sleigh and harness are meant for the wedding party.

- The tankard belonged to the celebration.

- The chest contained the dowry.

- The cushion-cover adorned the bridal bed.

- The porridge-container was for childbirth.

Thus the inventory of the collection mirrors a system of values associated with the selected objects. The vital force of the community was the family's instinct to survive; it was expressed in a set of key objects used for social rituals. In those objects the social position of its members was exposed, and the social hierarchy became evident.

I think that we can uncover many exciting stories in such studies of how collections were formed and what meanings they were intended to display. But it is necessary to approach the collections in a new way if we want to elicit their original messages.

What did Moltke Moe say in 1895 when promoting the idea to the new Norsk Folkemuseum? It was not necessary 


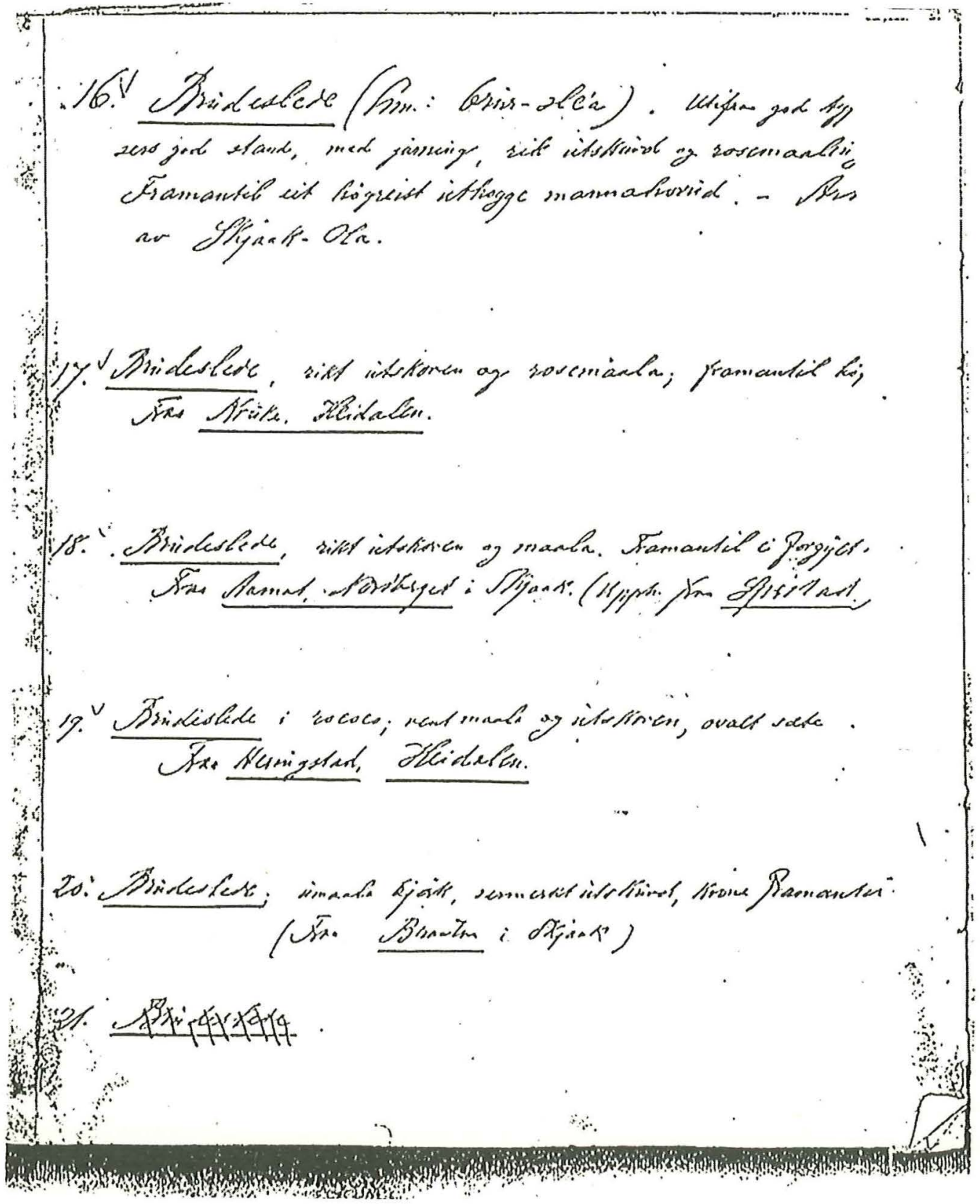

One page of the handwriting of the poet Olav Aukrust's (1883-1929) in the catalogue he made for the collection that became the local museum of Lom in Gudbrandsdalen. All objects listed here are 'sleighs for the weddings'. 
16 to bring the collections to Kristiania in order to save Norwegian folk culture '...because the objects are available in Stockholm for scholarly research'. But we know that the years 1894-95 were the most critical years in the political union between Norway and Sweden. And in such a crisis the Norwegian collection in the Nordic Museum in Stockholm was not enough:

Could our national identity feed on a collection in Stockholm? And the regard for what is honourable and becoming for the growth of our culture and the development of our nation? (Moe 1895, quoted by Aall 1920:3-5)

\section{MUSEUMS AND COMMUNICATION}

The visitors have not understood the collections in the way they should. They have wandered around in the museum halls and they have maybe been attracted by one thing or another, which they have found remarkably beautiful or rare, but only a minority of them have got any idea of what such collections really tell about our material, cultural and social development. (Aall 1930 according to Hegard 1994:88)

One basic aspect of museum collections is that the objects have two distinct qualities: as data and as medium. The understanding of that double meaning was perhaps more prominent among museum people before the object-related disciplines became dominant - simply because the whole collection was exhibited, or - as it was put in those days - everything was on show. But what kind of message was it intended that those heaps and rows of objects should convey?

Today it is quite proper to appraise criti- cally the epistemological basis of the museum message. It is quite acceptable to ask whether we perhaps find a knowledge that is out-of-date or even distorted in the message of the exhibitions.

According to the Norwegian archaeologist Bjørnar Olsen the museum is a disciplinary technique which came into being in the step from a premodern to a modern society. At such a stage a space was available in the museums for new concepts about history and reality.

Instead of being a mirror of the world, we can now perceive that the prevalent knowledge and its verbal expression contributed to shaping the world. Publications and museum exhibitions together created prehistory and with typological classification based on a finegraded system of measurement, prehistory could be given an objective existence. Even though museums perhaps did not create the development of archaeology as a discipline, they were a prerequisite for its success (Olsen/Svestad 1994:14).

It is impossible to discuss the role of the museums without reference to the relation between knowledge and power. It became necessary to separate amateurs and professionals - the archaeological statement was dependent on who made it:

In the same way as a serious medical statement to be accepted must be made by a physician, a serious archaeological statement must be made by a museum. (Olsen/Svestad 1994:16)

The museum with its show-cases "crammed with flint-axes, daggers, chisels and swords" exhibited an available and tangible prehistory (Olsen/Svestad 1994:18).

The archaeological museum had come 
close to the museum of natural history at the same time as evolutionism made its appearance as the new dominant paradigm. It meant a dramatic discarding of the biblical story of creation in favour of a scientific theory which depicted man in his nakedness as "an animal descended from other animals" (Hoch 1994:9).

The museums became powerful institutions for the visualization of the contents of the new paradigm, a way of understanding which - applied also to the material world - very soon became dominant in museums of cultural history. The changes in material culture are subsumed in a linear order, where simple objects are gradually followed by more complex and complicated forms. This mode of presentation achieved a prominence and has contributed to the spread and strengthening of the concept of evolution in the popular understanding of the regular development of culture from low to high forms (Ågren 1994:1-2).

From Darwin's theory which originally grew out of the study of nature, ideas were rapidly transferred to cultural development, not least because it suited the imperialistic view of the world with its contempt for the inferiority of other ethnic groups.

Turning back again to the Norsk Folkemuseum we find as one of the first publications from the museum Andreas $M$. Hansen's book The ancient Norseman. Origin and settlement (Oldtidens Nordmænd. Ophav og bosætning. 1907). The author thinks that he has observed a difference between the Finns who represented the oldest stone age in Norway and the Aryans arriving in the late stone age:
This sharp anthropological difference gives us reason to question the origins of Finns and Aryans. The geographic diffusion of brachycephalic types gives us strong evidence for a Finnish origin in Asia. It has been shown that the brachycephalic apes are also Asian; the African dolicocephalic. (Hansen 1907:127)

We recognize the evolutionist paradigm. He then goes on:

...the fact that the Negro, the Malayan, the Chinese and the Indian have different mentalities is agreed upon

Hansen writes, and at the same time he states that at the turn of the century there was no doubt about these truths.

But that there exist spiritual qualities common for the portion of our nation who are descended from the Aryans

in contrast to other countrymen, was not that well-known. Such is the point of his argument in the book. He discusses the difficulties of comparing spititual qualities:

spiritual qualities cannot be measured like height and the form of the skull.

Maybe not, but he has found an area where a statistical analysis can be made - political elections

Mass numbers for the diffusion of conservative and radical attitudes can be related to the racial pattern. (Hansen 1907:129)

Relating conservative attitudes to the form of the skull (which had been mapped) he found: 
JOHN AAgE GJESTRUM

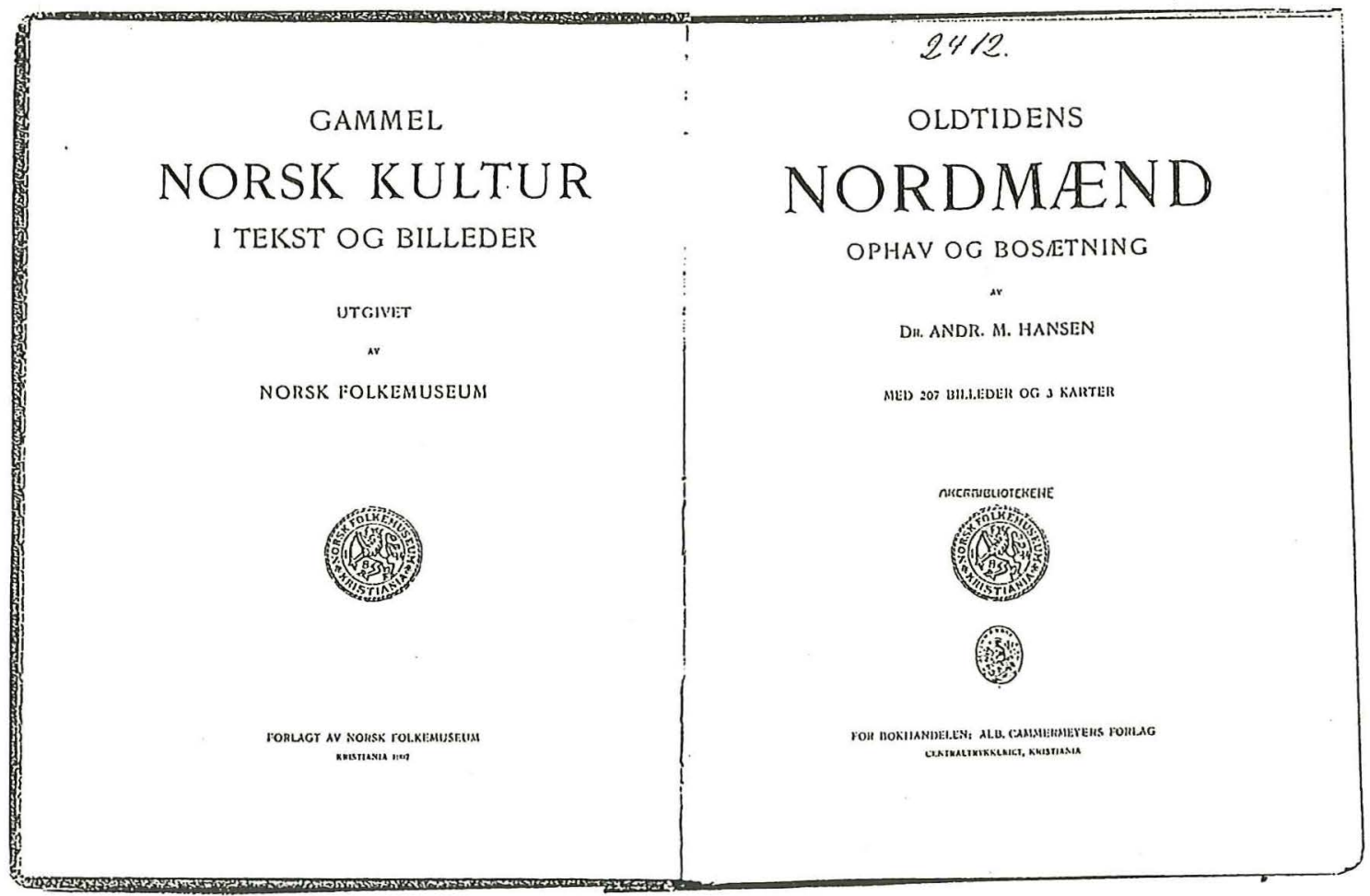

Norsk Folkemuseum, the Norwegian Folk Museum, was founded in 1894. So it could last year celebrate its centenary. This publication from 1907 in the series 'Old Norwegian Kulture in Texts and Illustrations' by Dr. Andreas M. Hansen illustrates how a museum actively promoted ideas that later would be considered as completely obsolete.

indisputable statistical evidence that brachycephalic individuals are conservative and that dolicocephalic individuals have a radical bent. (Hansen 1907:129)

The same pattern can be shown for Sweden, Denmark, Germany, France and Great Britain (Hansen 1907:130).

Is such a book worthy of mention today? Its scientific argument was dropped and forgotten long ago, the book is simply a curiosity.

But this does not seem to be true, if you compare it with the findings of the Swedish archaeologist Gundula Adolfsson. In her doctoral thesis from 1987 she studied some archaeological exhibitions in museums. There has been no qualified criticism applied to archaeological exhibitions, she says, and looking closely at 23 such exhibitions in Swedish museums she arrives at the conclusion that they are evolutionist, positivistic and utterly simplified school-books - and very similar to each other. 
She states that the chronological order of things typical of the permanent exhibitions certainly gives an impression that everything has improved through time and that we should appreciate our own conditions in the best of worlds. Such a view is never explicitly stated, but it becomes a side effect of the chronological story told through the arrangement of artefacts.

History told with rows of artefacts is based on two conditioning concepts which give rise to the misleading effect of evolutionary optimism:

- development and change are exhibited in simple limited sequences and for that reason are easily understandable;

- the visitor can use his own experience to test the validity of the representation of history. Development is perceived as logical and meaningful.

The objects are related more to their precursors and successors, less to environment, society and culture. "Development is reduced to technology and is described as a sort of technological evolution" (Adolfsson 1987:142-43). She has found two exceptions - one that links material culture to natural setting and environment, the other that links it to the social sphere.

In the permanent exhibitions man is described as unchanged through time, a homo technicus. Existential and philosophical issues are not dealt with. The exhibitions attempt to

answer questions about man, society and development once and for all, or at least for a long time. (Adolfsson 1987:215)

Positivistic thinking lends security both to exhibition producer and visitor. Positivism keeps at a distance elements which could upset scientific paradigms: spontaneity, speculation, scepticism, but first of all imagination. With positivism also comes the fear of new, unpredictable and incalculable things.

A daring questioning demands dauntless selfreflecting personalities, who could at least aim at alternative thinking. (Adolfsson 1987:215)

They are not to be found among today's museum curators according to Gundula Adolfsson.

She poses a lot of important questions in her book. One is the obvious influence of art history on the form of the exhibitions. Art history should fulfil two objectives: to explain aesthetic norms and to analyse the elements of the pictures so as to protect and save the works of art for an idealistic setting in time. Art forms are not necessarily at ease with their contemporary setting, but must be guarded for a future which is better prepared to re-establish the eternal aesthetic laws. Such an objective, to save history for a better future, was the basis for conservatism in cultural matters and for adding an aesthetic appeal to history (Kroll 1984:140, quoted by Adolfsson 1987).

The demand on history therefore is that it must be available for contemplation and that contemplation should be a pleasure. But it excludes a critical and analytical relation to history. When the past is given a beautiful form, a wishful thinking and nostalgia easily can enter in. One can recognize it in romantic landscape painting, represented in Norway by J.C.Dahl or in the ruins in Caspar David Friedrich's paintings. The Swiss art historian Jacob Burckhardt has coined the word "Trümmerhallen", ruin-halls. 
20 Equally false as Burckhardt's ruin-halls is the picture created in archaeological exhibitions with the aid of weaponry and pieces of jewellery. It speaks about harmony and nostalgia in a way that both veils and leaves out the social context. The past is disarmed, it does not ask for a moral judgement, it only asks to be consumed in a pleasant way. (Adolfsson 1987:123-24)

The aesthetization of history conveys a false emotionalism to the spectator, who perceives the aesthetic and exotic qualities as being inherent in the objects. The spectator assimilates the convention historians and archaeologists haved prepared for his education. Most exhibitions that have scored mass attendance have, according to Adolfsson, catered for the culinary appetite for history prevalent in a large public.

I think that that the questions she raises should be asked of many other types of museums and exhibitions. An important field of research lies here waiting to be explored, not least because museums today are being asked to increase public attendance. How does this quest for popular appeal influence the messages of the museums?

\section{CONCLUSIONS AND PERSPECTIVES}

In conclusion I will summarize my perspectives. But it is necessary to remark that there are many areas of research that I have not touched upon in my paper. The problem of selecting objects has been omitted as well as the theory of documentation: how to secure authenticity and relevance. Likewise the relationships between museums and society, between museology and object-oriented disciplines have not been discussed. All those matters are worthy of research. However I will give a summary of the five essential problems I have presented in my paper:

First, the long and apparently prevailing unwillingness among museum professionals to accept museology - what is its cause? It is also a well-known phenomenon in other countries. Are the well established disciplines and the professionals linked to them simply protecting their interests? Or is museology as yet such a young and incomplete subject with too little consensus about its substance, methodology and terminology?

Secondly; as an introduction I offered quotations from Professor Niemi and Professor Hohler. They have very clearly stated their position in the debate about the justification of museology. I hope to have defined a tenable basis from which to refute their views: museology is a relevant and important subject both for research and as an indispensable element in the studyprogramme for students aiming at careers in museums.

Thirdly; both the lack of consensus and the unwillingness in museums to discuss openly issues where there is professional disagreement, viz. the absence of an authentic professional discourse, is - as I have pointed out - reflected in the nature of the existing museological literature. In reality it is unclear what there is professional consensus about and what there is not. This is an unhealthy condition, which should be improved through museological research - and the level of the debate could be raised.

My fourth point: I have pointed to the fact that the study of ideologies of preservation as well as the creation and histories of museums can contribute to shedding 
new light on the function of museums Probably one might dare to guess that the origin of museums is not only linked to the initiatives of object-related disciplines.

The fifth and last point: The communication and outreach aspects of museums are not subjected to serious appraisal and evaluation. Museum people do not seem to care very much about the fact that so many exhibitions are based on outdated research, even though results and insights are available and ought to be communicated to the public. The evolutionary paradigm which seems to reign everywhere should be questioned and challenged and only research can offer a proper antidote.

Finally: the museum in itself and museology should be both offensive and defensive. The offensive museum participates in the shaping of our future and the construction of our cultural heritage; it works close to its public, its customers and users. The defensive museum protects the cultural memory for future use.

Offensive museology applies a critical view to museums and their work. Defensive museology defends the necessity to uphold the strict methodology of a scholarly discourse in contrast to limited and opinionated professional interests.

\section{NOTE}

The article is based on a paper presented at a symposium held at Norsk Folkemuseum, Oslo,

November 29th 1994.

Quotations from Neustupny (1968 and 1980) and Cameron (1992) are originally published in English. All other quotations are translated.

\section{REFERENCES}

Adolfsson, Gundula (1987): Människa och objekt $i$ smyckeskrin. En analys av arkeologiska utställningar $i$ Sverige. Stockholm - Lund

Cameron, Duncan Ferguson (1971): The Museum, a Temple or the Forum. Curator 14 1971/1, s. 11-24.

Cameron, Duncan Ferguson (1992): A Change of Heart. Museum Management and Curatorship 11, s. $375-386$

Hansen, Andreas M. (1907): Oldtidens Nordmend. Ophav og bosatning. Kristiania

Hegard, Tonte (1994): Hans Aall - mannen, visjonen og verket. Oslo

Hoch, Ella (1994): Museerne som arnen for det evolutionære verdensbillede. Nordisk Museologi $1994 / 2$, s. 3-20

Hohler, Erla B. (1994): Museologi - Myte eller Metode? In Helliesen, Sidsel og Tønseth, Britta (red.): $M$ for Museum. Rapport fra jubileumsseminar Oslo 3.-6. juni 1993 s. 37-42

Kloster, Robert (1972, formann): Innstilling fra komitéen til utredning av museenes stilling innen universitetsstrukturen. Bergen

Mensch, Peter van (1992): Towards a methodology of museology. Unpublished Dr. thesis, Zagreb

Neustupny, Jiri (1968): Museums and research. Praha

Neustupny, Jiri (1980): Museology as an academic discipline. $M u$ Wop - Museological Working Papers 1980/1, s. 28-29

Niemi, Einar (1994): Kommentar til Arnvid Lillehammers foredrag: Museenes mål - museenes midler - et tilbakeblikk. In Helliesen, Sidsel og Tønseth, Britta (red.): M for Museum. Rapport fra jubileumsseminar Oslo 3.-6. juni 1993 s. 2429

Olsen, Bjørnar og Svestad, Asgeir (1994): Creating prehistory: Archaeology museums and the discourse of modernism. Nordisk Museologi 1994/1, s. $3-20$ 
JOHN AAgE GJESTRUM

22 Pearce, Susan (1992): Museums, Objects and

Collections. A cultural Study. Leicester

Rudeng, Erik (1994): Bensin mellom søylene. In

Tschudi-Madsen, Stephan (red.): På nordmanns

vis. Norsk Folkkemuseum gjennom 100 arr. Oslo, s.

54-55

Shapiro, Michael Steven (1990) red.: The Museum:

A Reference Guide. New York - London -

Westport

Teather, J. Lynne (1983): Museology and its

Traditions. The British Experience 1845-1945.

Unpublished Dr. thesis, Leicester

Waidacher, Friedrich (1993): Handbuch der

Allgemeinen Museologie. Wien - Köln - Weimar

Woodhead, Peter og Stansfield, Geoffrey (1989):

Keyguide to information sources in Museum

Studies. London - New York

Åren, Per-Uno (1993): Museologi och kulturarv.

Nordisk Museologi 1993/1, s. 61-65

Ågren, Per-Uno (1994): Efter två år. Nordisk

Museologi 1994/2, s. 1-2

Aall, Hans (1920): Norsk Folkemuseum 1894-1919.

Trekk av dets historie. Kristiania

Aall, Hans (1925): Arbeide og ordning i kulturhistoriske museer. Kort veiledning. Oslo

John Aage Gjestrum is working on his doctoral thesis in museology at the Department of Museology, Umea University, supported by a scholarship from the

Norwegian National Council of Research. Norwegian editor of the journal Nordisk Museologi.

Adr: N-2846 Bøverbru, fax +47-61196013 